Apidologie, 1986, 17 (1), 21-32

\title{
GENETIC VARIATION IN HONEY BEES FROM AN AREA OF RACIAL HYBRIDIZATION IN WESTERN CZECHOSLOVAKIA
}

\author{
Walter S. SHEPPARD and Bruce A. McPHERON \\ Department of Entomology, University of Illinois \\ 320 Morrill Hall, 505 S. Goodwin Ave. Urbana, Illinois 61801
}

\section{SUMMARY}

Twelve colonies of honey bees from an area of hybridization between Apis mellifera mellifera and A.m. carnica in Czechoslovakia were electrophoretically examined at eighteen enzyme loci. The following five enzymes were found to exhibit polymorphism : malate dehydrogenase, esterase, malic enzyme, phosphoglucomutase and aconitase. The polymorphism for aconitase is reported here for the first time in the honey bee. Based on electrophoretic and morphometric data, many of the bees examined cannot be considered pure mellifera or carnica. The mean expected heterozygosity of $\boldsymbol{A}$. mellifera calculated from our data on 23 colonies of European honey bees was 0.038, approximately a threefold increase over previous estimates. Reasons are discussed for the increased mean heterozygosity and number of polymorphic loci found in European honey bees compared to U.S. honey bees.

\section{INTRODUCTION}

The western honey bee, Apis mellifera, is now distributed virtually world wide, although it is believed to have originated in the Near East (RuTTNER, 1975), southeast Asia and/or India (Rothenbuhler, 1979; Dietz, 1982) or Africa (WILSON, 1971). Regardless of its origin, A. mellifera subsequently spread throughout Europe, Africa and Western Asia where it differentiated into ove 20 recognized geographical races (RoTHENBUHLER et al., 1968). The differentiation of the European races of $\boldsymbol{A}$. mellifera has been attributed to fragmentation of honey bee populations during late Pleistocene glaciation (Culliney, 1983). Three of the major races that arose in Europe during this period were A. mellifera mellifera (the dark bee of Northern Europe), A. mellifera ligustica (the Italian bee) and $A$. mellifera carnica (the Carniolan bee).

The colonization of the New World by $A$. mellifera has taken place over the last 400 years as a result of deliberate importation by early European colonists and later by bee breeders. The exact number of colonies or queens of any 
particular race imported into the New World is unknown, although, as evidenced by recent data on enzyme polymorphism in European A.m. ligustica and A.m. mellifera, the importation appears to have represented a genetic bottleneck for the species (SHEPPARD and BERlocher, 1984, 1985). That is, the number of colonies imported was small enough that only part of the genetic variation of the species arrived in the New World and/or genetic drift in the founding populations eliminated some variation.

Of the three major European races introduced into the U.S., Apis mellifera carnic is one of the most recent, having been introduced into the country circa 1877 (Dadant, 1877). The Carniolans are native to Yugoslavia, Hungary, Romania, Bulgaria, and the southern part of the Austrian Alps, although today they are distributed widely throughout Europe and are second only to the Italian race (A.m. ligustica) in worldwide popularity (RUTTNER, 1975).

As part of a larger study of European honey bee races, we report here the results of a survey for enzyme polymorphism in honey bees collected from the regions of Bohemia and Moravia in Czechoslovakia. This area was originally populated by $A . m$. mellifera, but is now considered a zone of hybridization between $A . m$. mellifera and $A . m$. carnica (F. RUTTNER - personal communication). One reason for this is that, in Czechoslovakia, queens of $A . m$. carnica are propagated through artificial insemination and widely distributed to beekeepers (J. Ż $\hat{D} A R E K$ personal communication).

\section{MATERIALS AND ELECTROPHORESIS}

Adult workers were sampled from six different sites in western Czechoslovakia ranging form near the border of Poland in the north to near the Austrian border in the south (Fig. 1). Twelve colonies of honey bees were sampled, of which seven were of unknown ancestry and five were headed by queens of A.m. carnica background produced by the Czechoslovakian Research Institute of Apiculture [Vyzkumny ustar vcelarsky, Libcice] through artificial insemination. The samples were frozen and transported to the laboratory (University of Illinois, Urbana) on dry ice and stored at $-70^{\circ} \mathrm{C}$ until electrophoresis. Electrophoresis was performed on crude homogenates of head-thorax sections of individual bees (for details see ShepPard and Berlocher, 1984). Seventeen enzymes were assayed in this study, using a regimen of horizontal starch gel electrophoresis and buffer systems described previously (SHEPPARD and Berlocher, 1985). With the enzyme commission number in parentheses, these were : aconitase (E.C. 4.2.1.3); alpha-glycerophosphate dehydrogenase (E.C. 1.1.1.8); arginine kinase (E.C. 3.3.8.9) ; esterase (E.C. 3.1.1.1); glutamate dehydrogenase (E.C. 1.4.1.3) ; glyceraldehyde-3-phosphate dehydrogenase (E.C. 1.2.1.12); hexokinase (E.C. 2.7.1.1); beta-hydroxybutyrate dehydrogenase (E.C. 1.1.1.30); isocitrate dehydrogenase (E.C. 1.1.1.42); leucine aminopeptidase (E.C. 3.4.1.1); malate dehydrogenase (E.C. 1.1.1.37); malic enzyme (E.C. 1.1.1.40); phosphoglucomutase (E.C. 2.7.5.1) ; phosphoglucose isomerase (E.C. 5.3.1.9); and triose phosphate isomerase (E.C. 5.3.1.1). Enzyme activity was visualized with standard histochemical staining procedures (ShePPARd and BerLOCHER, 1984, 1985). In the honey bee, aconitase exhibits two putative loci, Acon-1 (cathodally migrating 


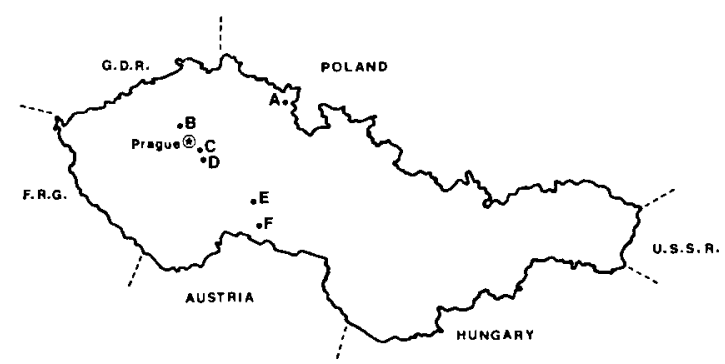

FIG. 1. - Collecting localities for Czechoslovakian Apis mellifera

$\mathrm{A}=$ Hronov, $\mathrm{B}=$ Libcice, $\mathrm{C}=$ Ricany, $\mathrm{D}=$ Senohraby $/$ Mirosovice, $\mathrm{E}=$ Jihlava, $\mathrm{F}=$ Telc.

isozymes) and Acon-2 (anodally migrating isozymes). For each of the remaining enzymes, only a single locus was scored. Adult workers of a colony of $A$. mellifera from a Champaign County Illinois apiary were run on each gel to serve as standards (see SHEPPARD and BerLocher, 1984). Following electrophoresis and staining, the gels were photographed for documentation and fixed in a 5:5:1 mixture of water, methanol and acetic acid. Allozyme designations are based on relative mobilities, with the fastest (MDH) or most common (ME, EST, PGM, ACON) allozymes used as standards (mobility 1.00). Decimal points are omitted in allozyme names.

The cutibal index of Goetze (RUTTNER, 1975) was measured in a subsample of all the colonies. Although not completely diagnostic, the cubital index (C.I.) has been reported to be quite different between mellifera (C.I. small ; 1.3-2.1) and carnica (C.I. very high ; 2.0-5.0) (RUTTNER, 1975).

\section{RESULTS}

Of the 17 enzyme systems (18 loci) examined, five exhibited polymorphism. Four of these polymorphisms, MDH, ME, EST, and PGM have been previously reported in the honey bee (MESTRINER, 1969; ConTEl et al., 1977 ; ShePpard and Berlocher, 1984, 1985 ; Del LAMA et al., 1985). ACON was also polymorphic and, although the ACON polymorphism is present in the U.S. (SHEPPARD unpublished data), this polymorphism is previously unreported in the honey bee. Colony allozyme frequencies for the polymorphic loci are reported in Table 1. Cubital indices are reported in Table 2.

The PGM polymorphism was present in five of the 12 czechoslovakian colonies and consisted of two allozymes, $\mathrm{Pgm}^{100}$ and $\mathrm{Pgm}^{75}$. The colonies exhibiting the PGM polymorphism were from three sites (B, C, F) (Fig. 1). PGM variation has recently been reported from colonies headed by German A.m. carnica queens and in "africanized" honey bees from Brazil (Del Lama et al., 1985). The $\mathrm{Pgm}^{100}$ and $\mathrm{Pgm}^{75}$ allozymes we found appear to be the «F allele 》 and « $M$ allele», respectively, of the PGM-1 locus reported by DEL LAMA and 
TABI. 1. - Allozyme frequencies of polymorphic enzym

\begin{tabular}{|c|c|c|c|c|c|c|c|c|c|}
\hline \multirow{2}{*}{ Colony/origin : } & \multicolumn{5}{|c|}{ Malate dehydrogenase } & \multicolumn{4}{|c|}{ Esterase } \\
\hline & $\mathbf{N}: ;:$ & Mdh5in & $\operatorname{Mdh}^{05}$ & $\operatorname{Mdh} 80$ & Mdh100 & $N * *$ & Estril & Est 100 & Est \\
\hline 1 - Hronov/A & 10 & 0.00 & 0.10 & 0.90 & 0.00 & 10 & 0.00 & 1.00 & \\
\hline 2-Hronov/A & 20 & 0.15 & 0.03 & 0.60 & 0.23 & 20 & 0.00 & 1.00 & \\
\hline 3 - Hronov/A & 20 & 0.10 & 0.03 & 0.80 & 0.08 & 20 & 0.00 & 1.00 & 0. \\
\hline $4-$ Libcice $/$ B + & 20 & 0.00 & 0.80 & 0.03 & 0.18 & 20 & 0.03 & 0.90 & 0.0 \\
\hline 5 - Libcice / B + & 20 & 0.00 & 0.75 & 0.18 & 0.08 & 20 & 0.03 & 0.90 & 0.0 \\
\hline 6 - Ricany/C & 18 & 0.00 & 0.61 & 0.08 & 0.31 & 18 & 0.00 & 0.86 & 0 . \\
\hline 7 - Ricany/C & 20 & 0.00 & 0.50 & 0.28 & 0.23 & 20 & 0.00 & 0.75 & 0.2 \\
\hline 8 - Senohraby/D & 28 & 0.00 & 0.59 & 0.00 & 0.41 & 30 & 0.00 & 0.98 & 0. \\
\hline 9 - Mirosovice/D & 30 & 0.00 & 0.32 & 0.28 & 0.40 & 30 & 0.00 & 0.68 & 0.3 \\
\hline $10-$ Jihlava $/ \mathbf{E}+$ & 19 & 0.00 & 0.55 & 0.21 & 0.24 & 19 & 0.00 & 1.00 & 0. \\
\hline $11 \cdot \mathrm{Telc} / \mathrm{F}+$ & 40 & 0.00 & 0.66 & 0.00 & 0.34 & 50 & 0.33 & 0.67 & 0. \\
\hline $12-\mathrm{Telc} / \mathrm{F}+$ & 19 & 0.00 & 0.47 & 0.00 & 0.53 & 19 & 0.24 & 0.76 & \\
\hline
\end{tabular}

* See figure 1 .

* Number of adult workers electrophoresed from each colony.

+ Colonies headed by artificially inseminated queens designated A.m. carnica (see text).

coworkers (ibid). To our knowledge, the crosses to determine the genetic basis of the PGM polymorphism have not been made.

The ACON polymorphism was present in a single colony from a central Bohemia site (D) and consisted of two allozymes, Acon- $2^{100}$ and Acon-2 $2^{120}$. In the honey bee, as in humans (HARRIS and HopKINSON, 1976), ACON is apparently a monomer, based on heterozygote staining patterns.

Using adult honey bees and our electrophoretic conditions only a single $\mathrm{MDH}$ locus is consistently scorable. This is probably the $M d h-1$ system described by ConTEL et al. (1977). MDH exhibited four allozymes, three of which, $\mathbf{N i d h}^{6 i}$ (S), $\mathrm{Mdh}^{80}$ (M) and $\mathrm{Mdh}^{100}$ (F), are well-known in the honey bee and are the only allozymes reported to date from U.S. populations. Another allozyme, $\mathrm{Mdh}^{\mathbf{5} 5}$, was present in two colonies from site $\mathrm{A}$, located approximately one $\mathrm{km}$ from Poland in northern Czechoslovakia.

EST was polymorphic in the Czechoslovakian honey bees and showed three allozymes, Est ${ }^{70}$, Est ${ }^{100}$ and Est ${ }^{130}$. Est ${ }^{100}$ is common in all European races and U.S. colonies we have studied (SHEPPARd and BErLocher, 1984, 1985 ; ShePPARD, unpublished data). The Est ${ }^{130}$ allozyme, known from A.m. ligustica and some U.S. colonies (Sheppard and BErlocher, 1985; ShEPpard, unpublished data), was present at three sites $(B, C, D)$ in northern and central Bohemia. 
in Czechoslovakian colonies of Apis mellifera

\begin{tabular}{|c|c|c|c|c|c|c|c|c|}
\hline \multicolumn{3}{|c|}{ Phosphoglucomutase } & \multicolumn{3}{|c|}{ Malic enzyme } & \multicolumn{3}{|c|}{ Aconitase } \\
\hline $\mathbf{N} * *$ & $\operatorname{Pgm} 75$ & Pgm.100 & $N^{* * *}$ & Me79 & Me100 & $\mathbf{N} * *$ & Acon- 2100 & Acon-2120 \\
\hline 10 & 0.00 & 1.00 & 10 & 0.00 & 1.00 & 10 & 1.00 & 0.00 \\
\hline 20 & 0.00 & 1.00 & 20 & 0.00 & 1.00 & 20 & 1.00 & 0.00 \\
\hline 20 & 0.00 & 1.00 & 20 & 0.00 & 1.00 & 20 & 1.00 & 0.00 \\
\hline 20 & 0.03 & 0.98 & 20 & 0.00 & 1.00 & 20 & 1.00 & 0.00 \\
\hline 20 & 0.03 & 0.98 & 20 & 0.03 & 0.98 & 20 & 1.00 & 0.00 \\
\hline 18 & 0.06 & 0.94 & 18 & 0.00 & 1.00 & 18 & 1.00 & 0.00 \\
\hline 20 & 0.08 & 0.93 & 20 & 0.00 & 1.00 & 20 & 1.00 & 0.00 \\
\hline 30 & 0.00 & 1.00 & 30 & 0.00 & 1.00 & 30 & 1.00 & 0.00 \\
\hline 30 & 0.00 & 1.00 & 30 & 0.00 & 1.00 & 30 & 0.97 & 0.03 \\
\hline 19 & 0.00 & 1.00 & 19 & 0.00 & 1.00 & 19 & 1.00 & 0.00 \\
\hline 50 & 0.01 & 0.99 & 50 & 0.00 & 1.00 & 49 & 1.00 & 0.00 \\
\hline 18 & 0.00 & 1.00 & 19 & 0.00 & 1.00 & 18 & 1.00 & 0.00 \\
\hline
\end{tabular}

TABL. 2. - Cubital index measurements of Czechoslovakian colonies of Apis mellifera

\begin{tabular}{|c|c|c|c|}
\hline \multirow{2}{*}{ Colony } & \multirow{2}{*}{$\mathbf{N}^{*}$} & \multicolumn{2}{|c|}{ Cubital index } \\
\hline & & Mean (S.D.) & Range \\
\hline 3-Hronov & 20 & $2.25(.295)$ & $1.41-2.59$ \\
\hline 2 - Hronov & 17 & $2.29(.311)$ & $1.85-3.04$ \\
\hline 10 - Jihlava + & 20 & $2.32(.187)$ & $2.03-2.73$ \\
\hline 1 - Hronov & 7 & $2.35(.228)$ & $2.04-2.64$ \\
\hline 9 - Mirosovice & 19 & $2.54(.311)$ & $1.85-3.15$ \\
\hline 6 - Ricany & 18 & $2.55(.322)$ & $2.18-3.3$ \\
\hline 4 - Libcicet & 20 & $2.72(.353)$ & $2.10-3.71$ \\
\hline 7 - Ricany & 20 & $2.74(.710)$ & $2.21-3.5$ \\
\hline 5-Libcicet & 20 & $2.76(.277)$ & $2.25-3.4$ \\
\hline $12-$ Telct & 21 & $3.00(.469)$ & $2.29-4.25$ \\
\hline $11-$ Telct & 20 & $3.22(.460)$ & $2.19-4.13$ \\
\hline 8 - Senohraby & 20 & $3.31(.491)$ & $2.64-4.25$ \\
\hline & & Mean & Range \\
\hline A.m. mellifera** & & $1.5-1.7$ & $1.3-2.1$ \\
\hline A.m. carnica** & & $2.4-3.0$ & $2.0-5.0$ \\
\hline
\end{tabular}

+ Colonies headed by artificially inseminated queens designated $A . m$. carnica (see text).

* Number of workers examined.

** RutTNER, 1975. 
Est $^{30}$ is reported here for the first time and occurred at two sites, one in northcentral Bohemia (B) and the other in southern Moravia (F). The four colonies in which the Est ${ }^{70}$ allozyme occurred were all headed by artificially inseminated A.m. carnica queens (Table 1). As in A.m. ligustica (Sheppard and Berlocher, 1985), the esterase allozymes reported here appear to be the esterase-3 system described by Bitondi and MESTRINER (1983).

The single colony that was polymorphic for ME was also headed by an artificially inseminated carnica queen in north-central Bohemia (B) and contained the allozymes $\mathrm{Me}^{79}$ and $\mathrm{Me}^{100}$. $\mathrm{Me}^{100}$ occurs in high frequency in all European races of $A$. mellifera for which it has been reported (SHEPPARD and Berlocher, 1984, 1985). Me ${ }^{79}$ has previously been reported only from A.m. mellifera from Norway (Sheppard and Berlocher, 1984). Malic enzyme is invariant (i.e., fixed for $\mathrm{Me}^{100}$ ) in New World A. mellifera studied to date (Sylvester, 1976 ; CONTEL et al., 1977).

The remaining thirteen loci appear to be monomorphic since the enzymes exhibited invariant banding patterns under our electrophoretic conditions. Both observed and expected heterozygosities were calculated for the Czechoslovakian and other European honey bees for which we have data (SHEPpard and BerioCHER, 1984, 1985). The $\overline{\mathbf{H}}$ estimates for the five artificially inseminated A.m. carnica colonies were not significantly different from the remaining 18 European colonies (Mann-Whitney $U$ test, $p>0.2)$; therefore the data were combined.

\section{DISCUSSION}

The honey bees from Czechoslovakia included in this study, while informative from the standpoint of containing heretofore unknown enzyme variants, cannot be considered representative of endemic populations of either geographic race, A.m. mellifera or A.m. carnica, for several reasons. Since the bees were collected from an area outside of the native range of carnica or were headed by artificially inseminated carnica queens derived from a selective breeding program, it is unlikely that they fully represent the variability of natural carnica populations. The presence of the $\mathrm{Me}^{79}$ allozyme, known previously only in $A . m$. mellifera, in one of the artificially inseminated carnica colonies, as well as the low C.I. of another (Jihlava-E), may indicate that some amount of hybridization between the races has occurred in this breeding program. The new EST allozyme, Est $^{i 0}$, which appears only in the colonies headed by artificially inseminated $A . m$. carnica queens, may be indicative of the carnica race, but additional electrophoretic studies will be needed to confirm this. 
Neither can these colonies be considered pure A.m. mellifera. The $\mathrm{Mdh}^{80}$ allozyme occurs in high frequency in mellifera from Norway (SHEPPARD and BERLOCHER, 1984) and is the sole Mdh allozyme ( $M \gg$ ) reported for mellifera from France (CoRnuet, 1982; Badino et al., 1983). However, $\mathrm{Mdh}^{80}$ occurs in relatively low frequency in all of the Czechoslovakian samples except those from near the Polish border (site A - Table 1). Moreover, the mean C.I. measurements of each of the colonies are out of the range for mellifera (Table 2). From both the C.I. and electrophoretic data (Tables 1 and 2), the most melliferalike bees in the present study were in the colonies of unknown ancestry collected from within one $\mathrm{km}$ of the Czechoslovakia - Poland border. Interestingly, Poland is considered one of the countries where populations of pure A.m. mellifera still exist (RUTTNER, 1975).

The results of this study indicate that our understanding of enzyme polymorphism and genetic variation in the honey bee is still in an early stage of development. In previous electrophoretic studies of New World A. mellifera, MDH, EST and PGM have been reported to be polymorphic in adult honey bees (Mestriner, 1969 ; Sylvester, 1976 ; Contel et al., 1977 ; Cornuet, 1979 ; Nunamaker, 1980 ; Del Lama et al., 1985). However, in the present study and other recent work (SHEPPARD and BERLOCHER, 1984, 1985) surveying a total of only 23 colonies from Norway, Italy and Czechoslovakia, two additional polymorphic enzymes (ME and ACON) were found, as well as three new allozymes $\left(\mathrm{Mdh}^{55}, \mathrm{Mdh}^{65}\right.$, $\left.\mathrm{Est}^{70}\right)$ for the previously known polymorphic enzymes.

Mean heterozygosity estimates reported for $A$. mellifera are quite low $(\overline{\mathrm{H}}=$ 0.010 - 0.012) (Sylvester, 1976 ; Pamilo et al., 1978) compared to non-hymenopteran insects $(\overline{\mathrm{H}}=0.120-0.135)$ (BERKElHamer, 1983; Graur, 1985) and even other Hymenoptera $(\overline{\mathrm{H}}=0.036-0.037)$ (ibid.). The basis for the apparent reduction of variability within the Hymenoptera has been discussed extensively (Lester and Selander, 1975 ; Metcalf et al., 1975 ; Pamilo et al., 1978 ; Berkelhamer, 1983 ; Graur, 1985 ; Sheppard and Heydon - submitted to Evolution) and need not be considered here. Estimates of $\overline{\mathrm{H}}$ calculated from the workers of eusocial colonies existing in managed apiaries are, in all probability, of little value in estimating the overall heterozygosity of the Hymenoptera (Graur, 1985 ; ShEPpard and HeYdon - submitted to Evolution), but may be useful in making comparisons among species which exhibit the same degree of sociality.

However, another reason for the reduced variability reported for Apis mellifera compared to other Hymenoptera may simply be a sampling problem. Pamilo's estimate (PAmILo et al., 1978) of heterozygosity was based on workers of A.m. mellifera from around Helsinki and may reflect the limited geographical area sampled, and SyLveSTER's (1976) estimate of heterozygosity in $A$. mellifera 
was based on populations sampled from the New World. The mean expected heterozygosity calculated from our data for 23 European honey bee colonies, $0.038\left(\overline{\mathrm{H}}_{\mathrm{obs}}=0.045\right)$, approximates the $\overline{\mathrm{H}}$ for the Hymenoptera in general. Thus, even these initial studies of European $A$. mellifera have revealed more than a threefold increase in mean heterozygosity over previous honey bee estimates.

We now know that the honey bee contains considerably more electrophoretic variation than has been previously realized. To more accurately quantify the amount of genetic variation in $A$. mellifera will require a rigorous sampling effort within areas of endemism, coupled with sequential electrophoresis and/or other molecular techniques. Such data for the geographic races of $A$. mellifera will make possible much more meaningful comparative studies with introduced populations such as those in Australia, South America and North America and will further elaborate the pattern and underlying causes of genetic diversity in the species.

Received for publication in June 1985. Accepted for publication in October 1985.

\title{
ACKNOWLEDGEMENTS
}

Without the extensive assistance of Dr Jan Ẑ̃ Academy of Science) this project would not have been possible. Oldrich Haragsim provided some of the bees used in this study. Professor Friedrich RutTNer made helpful suggestions for the manuscript and pointed out the area of hybridization between A.m. mellifera and A.m. carnica. We also thank M. R. Berenbaum, S.H. Berlocher, D.C. Smith and three anonymous reviewers for comments on the manuscript and S. FRIEDMAN for negotiations facilitating international transport. M. T. MCPHERon assisted in figure preparation.

\author{
RÉSUMÉ \\ VARIATION GENETIQUE DES ABEILLES \\ PROVENANT D'UNE ZONE D'HYBRIDATION RACIALE \\ DE TCHECOSLOVAQUTE OCCIDENTALE
}

Une analyse électrophorétique de 18 locus d'enzymes a été faite sur l'abeille carnolienne, Apis mellifica carnica. On a trouvé 5 locus d'enzymes polymorphiques dont 2 n'ont encore jamais été signalés chez l'abeille.

\section{Matériels et électrophorèse}

Des ouvrières adultes ont été prélevées dans 12 colonies de Tchécoslovaquie, puis congelées et transportées sur glace sèche à l'Université d'Illinois à Urbana-Champaign. L'électrophorèse horizontale sur gel d'amidon a été faite sur les portions tête-thorax d'abeilles. Les systèmes tampons et les conditions courantes ont déjà été décrites, (SHEPPARd et BERLocher, 1984, 1985). 
On a examiné les 18 locus d'enzymes suivants : aconitase-1, aconitase-2, $\alpha$-glycerophosphate déshydrogénase, arginine kinase, estérase, glutamate déshydrogénase, glyceraldéhyde-3-phosphate déshydrogénase, hexokinase, B-hydroxybuturate déshydrogénase, isocitrique déshydrogénase, leucine aminopeptidase, malate déshydrogénase, enzyme malique, phosphoglucomutase, phosphoglucose isomérase et triose phosphate isomérase.

\section{Résultats}

Cinq enzymes ont montré un polymorphisme chez Apis mellifica carnica. Il s’agit de : malate déshydrogénase, enzyme malique, estérase, phosphoglucomutase et aconitase. Le polymorphisme de laconitase est mentionné pour la première fois. Un nouvel allozyme d'estérase, Est ${ }^{70}$, présent dans seulement 4 sur les 5 colonies maintenues comme A.m. carnica, pourrait être indicateur de cette race. D'après les données électrophorétiques et morphométriques, de nombreuses abeilles examinées ne peuvent être considérées comme de pures mellifica ni de pures carnica. L'hétérozygocité moyenne attendue $\left(\overline{\mathbf{H}}_{\mathrm{exp}}\right)$, calculée pour l'abeille est de $\left.0,038\left(\mathbf{H}_{\mathrm{ob}, \mathrm{s}}\right)=0,045\right)$, soit une augmentation supérieure à 3 fois par rapport aux estimations précédentes. Les futures études électrophorétiques sur Apis mellifica conçues pour quantifier la variation génétique de l'espèce devraient utiliser des races géographiques endémiques d'Europe.

\section{ZUSAMMENF ASSUNG \\ GENETISCHE VARIATION VON HONIGBIENEN AUS EINEM GEBIET MIT RASSENHYBRIDEN IN DER WESTLICHEN CSSR}

Bei Bienen aus der CSSR wurde eine elektrophoretische Analyse von 18 Enzymen durchgeführt. Fünf Enzyme wurden als polymorph festgestellt; bei einem von ihnen war dies bisher bei der Honigbiene noch nicht bekannt.

\section{Material und Elektrophorese}

Aus 12 Völkern in der Tschechoslowakei (Abb. 1) wurden adulte Arbeitsbienen entnommen, eingefroren und in Trockeneis an die Universität von Illinois in Urbana-Champaign transportiert. Fünf von den 12 Völkern hatten künstlich besamte Könniginnen. An Kopf-Thorax-Schnitten individueller Bienen wurde eine horizontale Stärke-Gelanalyse durchgeführt. Puffersysteme und laufende Verfahren wurden früher beschrieben (SHEPPARD und BERLOCHER, 1984, 1985).

18 Enzym-Loci wurden untersucht : Aconitase-1, Aconitase-2, Alphaglyzerophosphat-Dehydrogenase, Arginin-Kinase, Esterase, Glutamat-Dehydrogenase, Glyceraldehyd-3-phosphat-Dehydrogenase, Hexokinase, Betahydroxybutyrat-Dehydrogenase, Isocitrat-Dehydrogenase, Leucin-Aminopeptidase, Malat-Dehydrogenase, Apfelsäure-Enzym, Phosphogluco-mutase, Phosphoglucose-Isomerase und Triosephosphat-Isomerase.

\section{Resultat und Diskussion}

Fünf Enzyme zeigten bei den untersuchten Bienen Polymorphismus. Es waren dies : MalatDehydrogenase, Apfelsäure-Enzym, Esterase, Phosphogluco-mutase und Aconitase. Über einen Polymorphismus bei Aconitase wird hier zum ersten Mal berichtet. Ein neues Esterase-Allozym, Est70, das in vier von fünf als Carnica eingestuften Völkern vorhanden war, könnte für diese Rasse charakteristisch sein. Auf der Grundlage von elektrophoretischen und morphometrischen Daten können viele untersuchte Bienen weder als reine Mellifera noch als reine Carnica betrachtet werden. Der Mittelwert der erwarteten Heterozygotie $\left(\mathrm{H}_{\mathrm{exp}}\right)$, der für die Honigbiene berechnet wurde, betrug 0,038, $\left(\overline{\mathbf{H}}_{\text {obs }}=0,045\right)$, eine mehr als dreifache Steigerung gegenüber früheren Schätzungen. Für 
künftige elektrophoretische Studien an der Honigbiene, die mit der Absicht durchgeführt werden, die genetische Variation in der Spezies zu quantifizieren, sollten endemische geographische Rassen der Alten Welt herangezogen werden.

\section{LITERATURE CITED}

Badino G., Celebrano G., Manino A., 1983. - Identificazione di Apis mellifera ligustica Spinola sulla base di sistemi gene-enzima. Boll. Mus. Reg. Sci. Nat. Torino, 1, 451-460.

Berkelhamer R.C., 1983. - Intraspecific genetic variation and haplodiploidy, eusociality, and polygyny in the Hymenoptera. Evolution, 37, 540-545.

Bitondi M.M.G., Mestriner M.A., 1983, - Esterase isozymes of Apis mellifera : Substrate and inhibition characteristics, developmental ontogeny, and electrophoretic variability. Biochem. Genet., 21 , 985-1002.

Contel E.P.B., Mestriner M.A., Martins E., 1977. - Genetic control and developmental expression of malate dehydrogenase in Apis mellifera. Biochem. Genet., 15, 859-876.

Connuet J.M., 1979. - The MDH system in the honeybees (Apis mellifera L.) of Guadaloupe. J. Hered., 70, 223-224.

CORnuet J.M., 1982. - The MDH polymorphism in some West Mediterranean honeybee populations. Proc. 9th Cong. I.U.S.S.J., Boulder (U.S.A.).

Culliney T.W., 1983. - Origin and evolutionary history of the honeybees Apis. Bee World, 64, 29-38.

Dadant C., 1877. - Cyprian and Carniolan bees. Amer. Bee J., 13, 27.

Del Lama M.A., Mestriner M.A., Paiva J.C.A., 1985. - EST-5 and PGM, New polymorphisms in Apis mellifera. Rev. Brasil, Genet., 8, 17-27.

Dietz A., 1982. - Honey bees. In : Social Insects. Volume III, edited by H.H. Herman, 323-360. Academic Press, New York.

Graur D., 1985. - Gene diversity in Hymenoptera. Evolution, 39, 190-199.

HaRris H., Hopkinson D.A., 1976. - Handbook of Enzyme Electrophoresis in Human Genetics. North Holland Co., Amsterdam/American Elsevier, New York.

Lester L.J., Selander R.K., 1979. - Population genetics of haplodiploid insects. Genetics, 92, 1329-1345.

Mestriner M.A., 1969. - Biochemical polymorphisms in bees (Apis mellifera ligustica). Nature, 223, $188-189$.

Metcalf R.A., Marlin J.C., Whitt G.S., 1975. - Low levels of genetic heterozygosity in Hymenoptera. Nature, 257, 792-794.

Nunamaker R.A., 1980. - Subspecies determination in the honey bee (Apis mellifera L.) based on isoelectric focusing of malate dehydrogenase. University of Wyoming, U.S.A., Phd Dissertation.

Pamilo P., Varvio-Aho S., Pekkarinen A., 1978. - Low enzyme gene variability in Hymenoptera as a consequence of haplodiploidy. Hereditas, 88, 93-99. 
Rothenbuhler W.C., 1979. - Semidomesticated insects : Honey bee breeding. In : Genetics in Relation to Insect Management. Edited by M.A. Hoy and J.J. McKelney, Jr., 84-92. Rockefeller Foundation, New York.

Rothenbuhler W.C., Kuliñ̈ević J.M., Kerr W.E., 1968. - Bee genetics. Ann. Rev. Genet., 2 , 413-438.

Ruttner F., 1975. - Races of bees. In : The Hive and the Honey Bee. Edited by Dadant and Sons, 19-38. Dadant and Sons, Hamilton, Illinois.

Sheppard W.S., Berlocher S.H., 1984. - Enzyme polymorphism in Apis mellifera from Norway. J. Apic. Res., 23, 64-69.

Sheppard W.S., Berlocher S.H., 1985. - New allozyme variability in Italian honey bees. J. Hered., 76, $45-48$.

Sheppard W.S., Heydon S.L. - High levels variability in three male-haploid species. Submitted to Evolution.

Sylvester H.A., 1976. - Allozyme variation in honey bees (Apis mellifera L.). University of California, Davis, U.S.A., Phd Dissertation.

Wilson E.O., 1971. - The Insect Societies, Harvard Univ, Press, Cambridge, Mass. 